\title{
SOLVABILITY OF THE SHOWALTER-SIDOROV PROBLEM FOR SOBOLEV TYPE EQUATIONS WITH OPERATORS IN THE FORM OF FIRST-ORDER POLYNOMIALS FROM THE LAPLACE-BELTRAMI OPERATOR ON DIFFERENTIAL FORMS
}

\author{
D. E. Shafranov ${ }^{1}$, shafranovd@mail.ru, \\ N. V. Adukova ${ }^{1}$, adnatasha94@mail.ru. \\ ${ }^{1}$ South Ural State University, Chelyabinsk, Russian Federation
}

\begin{abstract}
We consider solvability of the Showalter-Sidorov problem for the Barenblatt-ZheltovKochina equations and the Hoff linear equation. The equations are linear representatives of the class of linear Sobolev type equations with an irreversible operator under derivative. We search for a solution to the problem in the space of differential k-forms defined on a Riemannian manifold without boundary. Both equations are the special cases of an equation with operators in the form of polynomials of the first degree from the Laplace-Beltrami operator, generalizing the Laplace operator in spaces of differential $k$-forms up to a sign. Applying the Sviridyuk theory and the Hodge-Kodaira theorem, we prove an existence of the subspace in which there exists a unique solution to the problem.

Keywords: Sobolev type equation, Riemannian manifolds, manifold without boundary, differential forms, Laplace-Beltrami operator
\end{abstract}

\section{Introduction}

The Barenblatt-Zheltov-Kochina equation

$$
(\lambda-\Delta) u_{t}=\alpha_{1} \Delta u
$$

which simulates dynamics of the pressure of a viscoelastic fluid filtering in fractured porous media [1], and linearization of the Hoff equation

$$
(\lambda-\Delta) u_{t}=\alpha_{0} u
$$

which simulates the process of I-beam buckling under load, for low pressure and high temperature [2], can be understood as concrete interpretations of the abstract linear equation of the Sobolev type (with ker $L \neq\{0\}$ )

$$
L \dot{u}=M u \text {. }
$$

These equations and various initial-boundary value problems for them in Banach spaces are widely studied in the scientific school of G.A. Sviridyuk. The general theory of solvability for various cases is presented in [3]. Let operators $L, M \in \mathcal{L}(\mathfrak{U} ; \mathfrak{F})$ be linear and continuous, and the space $\mathfrak{U}$ be presented as a direct sum $\mathfrak{U}=\mathfrak{U}^{0} \oplus \mathfrak{U}^{1}$.

In this paper we study the Showalter-Sidorov problem [4]

$$
P\left(u(0)-u_{0}\right)=0,
$$


for an equation with operators $L, M$ in the form of polynomials from the Laplace - Beltrami operator

$$
\left(\kappa_{0}+\kappa_{1} \Delta\right) u_{t}=\left(\alpha_{0}+\alpha_{1} \Delta\right) u
$$

where $L$ is a polynomial of the first order $\left(\kappa_{1} \neq 1\right), M$ is a polynomial of the first or zero order, and the roots of the polynomials are different, that is $\frac{\kappa_{0}}{\kappa_{1}} \neq \frac{\alpha_{0}}{\alpha_{1}}$. Positive signs under Laplacians are related to the fact that we take pseudodifferential Laplace-Beltrami operator acting in spaces of differential $k$-forms $\mathfrak{H}^{k}=\mathfrak{H}^{k}\left(\Omega_{n}\right)$ defined on Riemannian manifold without boundary $\Omega_{n}$, which generalizes the Laplace operator only up to the sign [5]. The Cauchy problem for Sobolev type equations in spaces of $k$-forms defined on a Riemannian manifold without boundary was investigated, for example, in [6]. Here we consider the Showalter-Sidorov problem described in detail in [4]. Similar problems were investigated in other spaces in the papers [7] and [8], where polynomials of arbitrary order with real and complex coefficients from the Laplace operator are used as operators $L, M$, respectively.

The article includes Introduction, three paragraphs and References. The first two paragraphs contain the preliminary information. Required information from the abstract theory [3] of linear Sobolev type equations (3) is presented in paragraph 1. The HodgeKodaira theory for the Laplace-Beltrami operator on $k$-forms and its applications extracted from [5], [10], [11] are written in our notations in paragraph 2. In paragraph 3 we show reduction of the Showalter-Sidorov problem (4) for the equation (5) to an abstract linear Sobolev type equation and return to the Barenblatt-Zheltov-Kochina equations (1) and linearization of the Hoff equations (2), as particular cases of the equation (5). References do not pretend for completeness, but only follow the preferences of the authors.

\section{The Showalter-Sidorov Problem for Abstract Sobolev Type Equations}

Let $\mathfrak{U}$ and $\mathfrak{F}$ be Banach spaces, the operators $L, M \in \mathcal{L}(\mathfrak{U} ; \mathfrak{F})$. Consider [3] $L$-resolvent set

$$
\rho^{L}(M)=\left\{\mu \in \mathbb{C}:(\mu L-M)^{-1} \in \mathcal{L}(\mathfrak{F} ; \mathfrak{U})\right\}
$$

and $L$-spectrum $\sigma^{L}(M)=\mathbb{C} \backslash \rho^{L}(M)$ of the operator $M$. If $L$-spectrum $\sigma^{L}(M)$ of the operator $M$ is bounded, then the operator $M$ is called $(L, \sigma)$-bounded. If the operator $M$ is $(L, \sigma)$-bounded, then there exist projectors

$$
P=\frac{1}{2 \pi i} \int_{\gamma} R_{\mu}^{L}(M) d \mu \in \mathcal{L}(\mathfrak{U}), \quad Q=\frac{1}{2 \pi i} \int_{\gamma} L_{\mu}^{L}(M) d \mu \in \mathcal{L}(\mathfrak{F}) .
$$

Here $R_{\mu}^{L}(M)=(\mu L-M)^{-1} L$ and $L_{\mu}^{L}(M)=L(\mu L-M)^{-1}$ is right and left L-resolvent of the operator $M$, respectively, and the closed contour $\gamma \subset \mathbb{C}$ bounds a domain containing $\sigma^{L}(M)$.

We set $\mathfrak{U}^{0}\left(\mathfrak{U}^{1}\right)=\operatorname{ker} P(\operatorname{im} P), \mathfrak{F}^{0}\left(\mathfrak{F}^{1}\right)=\operatorname{ker} Q(\operatorname{im} Q)$ and denote restriction of the operator $L(M)$ on $\mathfrak{U}^{k}, k=0,1$ by $L_{k}\left(M_{k}\right)$.

Theorem 1. (Splitting theorem). Let operator $M$ be $(L, \sigma)$-bounded, then

(i) operators $L_{k}\left(M_{k}\right) \in \mathcal{L}\left(\mathfrak{U}^{k} ; \mathfrak{F}^{k}\right), k=0,1$;

(ii) there exist operators $M_{0}^{-1} \in \mathcal{L}\left(\mathfrak{F}^{0} ; \mathfrak{U}^{0}\right)$ and $L_{1}^{-1} \in \mathcal{L}\left(\mathfrak{F}^{1} ; \mathfrak{U}^{1}\right)$. 
Proof. Construct operators $H=M_{0}^{-1} L_{0} \in \mathcal{L}\left(\mathfrak{U}^{0}\right), S=L_{1}^{-1} M_{1} \in \mathcal{L}\left(\mathfrak{U}^{1}\right)$.

Corollary 1. Let operator $M$ be $(L, \sigma)$-bounded, then for all $\mu \in \rho^{L}(M)$

$$
(\mu L-M)^{-1}=-\sum_{k=0}^{\infty} \mu^{k} H^{k} M_{0}^{-1}(\mathbb{I}-Q)+\sum_{k=1}^{\infty} \mu^{-k} S^{k-1} L_{1}^{-1} Q .
$$

An operator $M$ is called $(L, p)$-bounded, $p \in\{0\} \cup \mathbb{N}$, if $\infty$ is a removable singular point (that is, $H \equiv \mathbb{O}, p=0$ ) or a pole of order $p \in \mathbb{N}$ (that is, $H^{p} \neq \mathbb{O}, H^{p+1} \equiv \mathbb{O}$ are $L$-resolvents $(\mu L-M)^{-1}$ of the operator $\left.M\right)$.

Let operator $M$ be $(L, p)$-bounded, $p \in\{0\} \cup \mathbb{N}$. Consider for the homogeneous equation

$$
L \dot{u}=M u
$$

the initial Showalter-Sidorov condition

$$
\left[R_{\alpha}^{L}(M)\right]^{p+1}\left(u(0)-u_{0}\right)=0 .
$$

Definition 1. A set $\mathfrak{P} \subset \mathfrak{U}$ is called a phase space of the equation (6), if

(i) any trajectory of the solution $u=u(t)$ lies in $\mathfrak{P}$ pointwise, that is $u(t) \in \mathfrak{P}$ for all $t \in \mathbb{R}$

(ii) for any initial condition $u_{0} \in \mathfrak{P}$ there exists the unique solution $u \in C^{\infty}(\mathbb{R} ; \mathfrak{U})$ to the problem (6), (7).

Theorem 2. Let operator $M$ be $(L, p)$-bounded, $p \in\{0\} \cup \mathbb{N}$. Then phase space of the equation (6) is the subspace $\mathfrak{U}^{1}$.

Definition 2. A map $U^{\bullet} \in C^{\infty}(\mathbb{R} ; \mathcal{L}(\mathfrak{U}))$ is called a group of resolving operators, if

$$
U^{s} U^{t}=U^{s+t} \text { for all } s, t \in \mathbb{R} .
$$

A group $\left\{U^{t}: t \in \mathbb{R}\right\}$ is called holomorphic, if the group is analytically continued to the entire complex plane with preserving the property (8); and degenerate, if its unit $U^{0} \in \mathcal{L}(\mathfrak{U})$ is a projection.

Theorem 3. Let operator $M$ be $(L, \sigma)$-bounded. Then there exists the unique resolving group of the equation (6)

$$
U^{t}=\frac{1}{2 \pi i} \int_{\gamma} R_{\mu}^{L}(M) e^{\mu t} d \mu, \quad t \in \mathbb{R}
$$

Here $\gamma \subset \mathbb{C}$ is the same contour as in projectors $P, Q$. Note that unit of the group (8) is the projector $P$.

By Theorem $1, U^{t}=\mathbb{O}(\mathbb{I}-P)+e^{t S} P$.

And, by the same theorem, the condition (7) is equivalent to the condition:

$$
P\left(u(0)-u_{0}\right)=0 .
$$

Therefore, the following lemma holds.

Lemma 1. Let operator $M$ be $(L, p)$-bounded, $p \in\{0\} \cup \mathbb{N}$. Then for any $u_{0} \in \mathfrak{U}^{1}$ there is a unique solution $u \in C^{\infty}(\mathbb{R}, \mathfrak{U})$ to the problem (6), (7), which has the form $u(t)=U^{t} u_{0}$, $t \in \mathbb{R}$. 


\section{Hodge-Kodaira Theory for the Laplace-Beltrami Operator in the Space of $k$-forms on a Riemannian Manifold without Boundary}

Let $\Omega_{n}$ be a smooth compact orientable $n$-dimensional Riemannian manifold without boundary. Denote a space of differential $k$-forms on $\Omega_{n}$ by $H^{k}=H^{k}\left(\Omega_{n}\right), 0 \leq k \leq n$. Note that $H^{0}\left(\mathbb{R}^{n}\right)$ is the space of functions of $n$ variables.

There exists a linear Hodge operator $*: H^{k} \rightarrow H^{n-k}$, which maps a $k$-form on $\Omega$ to the $(n-k)$-form, and the equality $* *=(-1)^{k(n-k)}$ is true.

There is an operator for taking an external differential $d: H^{k} \rightarrow H^{k+1}$. Define the operator $\delta: H^{k} \rightarrow H^{k-1}$ such that

$$
\delta=(-1)^{n(k+1)+1} * d *
$$

which on 0 -forms is a zero linear functional.

Definition 3. The Laplace-Beltrami operator $\Delta: H^{k} \rightarrow H^{k}$ (or breifly, Laplacian) is defined by the equality

$$
\Delta=\delta d+d \delta
$$

and is a linear operator on the space $H^{k}, 0 \leq k \leq n$.

Remark 1. On smooth functions in Euclidean space $\mathbb{R}^{n}$ (that is, in $H^{0}\left(\mathbb{R}^{n}\right)$ ) the Laplacian coincides with $(-1) \sum_{i=1}^{n} \frac{\partial^{2}}{\partial x_{i}^{2}}$.

Definition 4. Define a space of harmonic $p$-forms as

$$
H_{\Delta}^{k}=\left\{\omega \in H^{k}: \Delta \omega=0\right\} .
$$

Theorem 4. (Hodge decomposition theorem). For any integer $k, 0 \leq k \leq n$, the space $H_{\Delta}^{k}$ is finite-dimensional and there exists the following decomposition of the space of smooth $k$-forms on $\Omega_{n}$ in orthogonal direct sum

$$
H^{k}=\Delta\left(H^{k}\right) \oplus H^{k}=d \delta\left(H^{k}\right) \oplus \delta d\left(H^{k}\right) \oplus H_{\Delta}^{k} .
$$

Therefore, the equation $\Delta \omega=\alpha$ has a solution $\omega \in\left(H_{\Delta}^{k}\right)^{\perp}$, when $k$-form $\alpha$ is orthogonal to the space of harmonic forms.

Define a scalar product in space $H^{k}, k=0,1, \ldots, n$ by the formula

$$
(\xi, \eta)_{0}=\int_{\Omega_{n}} \xi \wedge * \eta, \xi, \eta \in H^{k},
$$

where $*$ is the Hodge operator. Denote the corresponding norm by $\|\cdot\|_{0}$. Continue the scalar product (12) to the direct sum $\bigoplus_{k=0}^{n} H^{k}$ such that different spaces $H^{k}$ are orthogonal. Denote a completion of the space $H^{k}$ with respect to the norm $\|\cdot\|_{0}$ by $\mathfrak{H}_{0}^{k}$, and an orthogonal projection on $\mathfrak{H}_{\Delta}^{k}$ by $P_{k \Delta}$.

Introduce a scalar product on $H^{k}$ by the formulas

$$
(\xi, \eta)_{1}=(\Delta \xi, \eta)_{0}+\left(\xi_{\Delta}, \eta_{\Delta}\right)_{0}
$$




$$
(\xi, \eta)_{2}=(\Delta \xi, \Delta \eta)_{0}+(\xi, \eta)_{1},
$$

where $\omega_{\Delta}=P_{k \Delta} \omega$. Denote a completion of the lineal $H^{k}$ with respect to the corresponding norms $\|\cdot\|_{1}$ and $\|\cdot\|_{2}$ by $\mathfrak{H}_{1}^{k}$ and $\mathfrak{H}_{2}^{k}$, respectively.

Remark 2. In fact, the superscript means how many times $k$-forms in the corresponding spaces are differentiable in the generalized sense.

The spaces $\mathfrak{H}_{l}^{k}, l=1,2$, are Banach spaces (their Hilbert structure is not of interest in the future), and there are continuous and dense imbeddings $\mathfrak{H}_{2}^{k} \subset \mathfrak{H}_{1}^{k} \subset \mathfrak{H}_{0}^{k}$. There is the following corollary.

Corollary 2. For any $k=0,1, \ldots, n$ there exist splittings of the spaces

$$
\mathfrak{H}_{l}^{k}=\mathfrak{H}_{l}^{k \perp} \oplus \mathfrak{H}_{\Delta}^{k}
$$

where $\mathfrak{H}_{l}^{k \perp}=\left(\mathbb{I}-P_{k \Delta}\right)\left[\mathfrak{H}_{l}^{k}\right], l=0,1,2$.

\section{The Showalter-Sidorov Problem for an Equation with Operators in the Form of Polynomials from the Laplace- Beltrami Operator}

Divide the equation (5) by the coefficient $\kappa_{1}$ and get the equation

$$
(\lambda+\Delta) u_{t}=\left(\tau_{0}+\tau_{1} \Delta\right) u
$$

where

$$
\lambda=\frac{\kappa_{0}}{\kappa_{1}}, \tau_{0}=\frac{\alpha_{0}}{\kappa_{1}}, \tau_{1}=\frac{\alpha_{1}}{\kappa_{1}} .
$$

Consider the Showalter-Sidorov problem

$$
P\left(u(0)-u_{0}\right)=0 .
$$

Denote the spaces $\mathfrak{U}=\bigoplus_{k=0}^{n} \mathfrak{H}_{2}^{k}, \mathfrak{F}=\bigoplus_{k=0}^{n} \mathfrak{H}_{0}^{k}$. Next, define the operators $L, M$ by the formulas

$$
L=\lambda \mathbb{I}+\Delta, M=\tau_{0} \mathbb{I}+\tau_{1} \Delta .
$$

The spectrum of the Laplace-Beltrami operator $\sigma(\Delta)$ is a countable set of non-negative eigenvalues of finite multiplicity condensing only at the point $+\infty$. Denote the set by a sequence $\left\{\lambda_{k}\right\}$ numbered according to multiplicity. Denote eigenfunctions by $\left\{\varphi_{k}\right\}$.

By the Atiyah-Singer theorem [12] the operator $L$ is Fredholm. There is the following lemma.

Lemma 2. For any $\lambda \in \mathbb{R} \backslash\{0\}, \tau_{0}, \tau_{1} \in \mathbb{R}$ and fixed $k=0,1, \ldots, n$ the operator $M$ is $(L, 0)$-bounded.

Proof.

Calculate limit of the sequence $\left\{\mu_{k}\right\}=\left\{\frac{\tau_{0}+\tau_{1} \lambda_{k}}{\lambda+\lambda_{k}}\right\}$. Since $\lambda_{k} \mapsto+\infty$, then

$$
\lim _{\lambda_{k} \mapsto+\infty} \mu_{k}=\lim _{\lambda_{k} \mapsto+\infty} \frac{\tau_{0}+\tau_{1} \lambda_{k}}{\lambda+\lambda_{k}}=\left[\frac{\infty}{\infty}\right]=\tau_{1}, \text { if } \tau_{1} \neq 0
$$




$$
\lim _{\lambda_{k} \mapsto+\infty} \mu_{k}=\lim _{\lambda_{k} \mapsto+\infty} \frac{\tau_{0}+\tau_{1} \lambda_{k}}{\lambda+\lambda_{k}}=\left[\frac{c}{\infty}\right]=0 \text {, if } \tau_{1}=0 .
$$

Note that the limit is finite. Therefore, there is a removable singular point, which corresponds to a pole of order $p=0$. The sequence is bounded, because it converges.

For $\lambda \in \sigma(\Delta)$ the phase space is

$$
\mathfrak{U}^{1}=\mathfrak{U},
$$

and for $\lambda \notin \sigma(\Delta)$

$$
\mathfrak{U}^{1}=\left\{u \in \mathfrak{U}:\left(u, \varphi_{k}\right)_{0}=0, \lambda=\lambda_{k}\right\} .
$$

By Lemma 1, the reduction carried out leads us to the following

Theorem 5. For any $\lambda \in \mathbb{R} \backslash\{0\}, \tau_{0}, \tau_{1} \in \mathbb{R}$ and $u_{0} \in \mathfrak{U}^{1}$ there is a unique solution $u \in C^{\infty}(\mathbb{R}, \mathfrak{U})$ to the problem (15), (16).

\section{References}

1. Barenblatt G.I., Zheltov Iu.P., Kochina I.N. Basic concepts in the theory of seepage of homogeneous liquids in fissured rocks [strata]. Journal of Applied Mathematics and Mechanics, 1960, vol. 24, no. 5, pp. 1286-1303. doi:10.1016/0021-8928(60)90107-6

2. Hoff N.A. Greep buckling. Aeronautics, 1965, vol. 7, no. 1. pp. 1-20.

3. Sviridyuk G.A., Manakova N.A. The Dynamical Models of Sobolev Type with Showalter-Sidorov Condition and Additive "Noise". Bulletin of the South Ural State University, Series: Mathematical Modelling, Programming and Computer Software, 2014, vol. 7, no. 1, pp. 90-103. doi: 10.14529/mmp140108. (in Russian)

4. Sviridyuk G.A., Zargebina S.A. The Showalter-Sidorov problem as a phenomena of the Sobolev-type equations. , 2010, vol. 3, no. 1, pp. 104-125. (in Russian)

5. Warner F. Foundations of Differentiable Manifolds and Lie Groups. N.-Y.; Berlin; Heidelberg; Tokyo, Springer-Verlag, 1983. doi: 10.1007/978-1-4757-1799-0

6. Shafranov D.E., Shvedchikova A.I. The Hoff Equation as a Model of Elastic Shell. Bulletin of the South Ural State University, Series: Mathematical Modelling, Programming and Computer Software, 2012, issue 12, pp. 77-81. (in Russian)

7. Zamyshlyaeva A.A., Al-Isawi D.K.T. On Some Properties of Solutions to One Class of Evolution Sobolev Type Mathematical Models in quasi-Sobolev Spaces. Bulletin of the South Ural State University, Series: Mathematical Modelling, Programming and Computer Software, 2015, vol. 8, no. 4, pp. 113-119. doi: 10.14529/mmp150410

8. Sagadeeva M.A., Hasan F.L. Bounded solutions of Barenblatt-Zheltov-Kochina model in quasi-Sobolev spaces. Bulletin of the South Ural State University, Series: Mathematical Modelling, Programming and Computer Software, 2015, vol. 8, no. 4, pp. 138-144. doi: https://doi.org/10.14529/mmp150414 (in Russian)

9. Sviridyuk G.A., Fedorov V.E. Linear Sobolev Type Equations and Degenerate Semigroups of Operators. Utrecht-Boston, VSP, 2003. 
10. Dezin A.A. [Multivariate Analysis and Discrete Models]. Novosibirsk, Nauka, 1990. (in Russian)

11. Maurin K. Metody Przestrzeni Hilberta. Warsawa, Państwowe Wydawnictwo Naukowe, 1959. (in Polish)

12. Palais R. Seminar on the Atiyah-Singer Index Theorem. Princeton, Princeton University Press, 1965.

Dmitry E. Shafranov, PhD (Math), Associate Professor of the Department of Equations of Mathematical Physics, South Ural State University (Chelyabinsk, Russian Federation), shafranovd@mail.ru

Natalia E. Adukova, Graduate Student of the Department of Equations of Mathematical Physics, South Ural State University (Chelyabinsk, Russian Federation), shafranovd@mail.ru

Received June 23, 2017

УДК 517.9

DOI: $10.14529 /$ jcem170304

РАЗРЕШИМОСТЬ ЗАДАЧИ ШОУОЛТЕРА-СИДОРОВА ДЛЯ УРАВНЕНИЙ СОБОЛЕВСКОГО ТИПА С ОПЕРАТОРАМИ В ВИДЕ ПОЛИНОМОВ 1-ГО ПОРЯДКА ОТ ОПЕРАТОРА ЛАПЛАСА-БЕЛЬТРАМИ НА ДИФФЕРЕНЦИАЛЬНЫХ ФОРМАХ

\author{
Д.Е. Шафранов, Н.В. Адукова
}

\begin{abstract}
В работе исследуется разрешимость задачи Шоуолтера-Сидорова для уравнений Баренблатта-Желтоватых-Кочиной и линейного уравнения Хоффа являющихся линейными представителями класса линейных уравнений соболевского типа, с необратимым оператором при производной. Решение ищется в пространстве дифференциальных k-форм, определенных на римановом многообразии без края. Оба уравнения будут частным случаем уравнения с операторами в виде многочленов 1-ой степени от оператора Лапласа-Бельтрами, обобщающий оператор Лапласа с точностью до знака в пространствах дифференциальных k-форм.

Применяя теорию Свиридюка и теорему Ходжа-Кодаира получается доказать существования подпространства в котором существует единственное решение задачи.

Ключевые слова: уравнения соболевского типа, римановы многообразия, многообразие без края, дифберенииальные формы, оператор Лапласа-Бельтрами
\end{abstract}

\title{
Литература
}

1. Баренблатт, Г.И. Об основных представлениях теории фильтрации в трещинноватых средах / Г.И. Баренблатт, Ю.П. Желтов, И.Н. Кочина // ПММ. - 1960. T. 24, № 5. - C. 58-73.

2. Hoff, N.A. Greep buckling / N.A. Hoff // Aeronautics. - 1965. - V. 7, № 1. - P. 1-20. 
3. Свиридюк, Г.А. Динамические модели соболевского типа с условием ШоуолтераСидорова и аддитивными "шумами" / Г.А. Свиридюк, Н.А. Манакова // Вестник ЮУрГУ. Серия: Математическое моделирование и программирование. - 2014. T. 7, № 1. - C. 90-103.

4. Свиридюк, Г.А. Задача Шоуолтера-Сидорова как феномен уравнений соболевского типа / Г.А. Свиридюк, С.А. Загребина // Известия Иркутского гос. ун-та. Сер. "Математика". - 2010. - Т. 3, № 1. - С. 104-125.

5. Уорнер, Ф. Основы теории гладких многообразий и групп Ли / Ф. Уорнер. - М.: Мир, 1987.

6. Шафранов, Д. Е. Уравнение Хоффа как модель упругой оболочки / Д.Е. Шафранов, А.И. Шведчикова // Вестник ЮУрГУ. Серия: Математическое моделирование и программирование. - 2012. - вып. 12. - С. 77-81.

7. Замышляева, A.A. On Some Properties of Solutions to One Class of Evolution Sobolev Type Mathematical Models in quasi-Sobolev Spaces / A.A. Замышляева, Дж.К.Т. Аль-Исави // Вестник ЮУрГУ. Серия: Математическое моделирование и программирование. - 2015. - Т. 8, № 4. - С. 113-119.

8. Сагадеева, М.А. Ограниченные решения модели Баренблатта-Желтова-Кочиной в квазисоболевских пространствах / М.А. Сагадеева, Ф.Л. Хасан // Вестник ЮУрГУ. Серия: Математическое моделирование и программирование. - 2015. T. 8, № 4. - C. 138-144.

9. Sviridyuk, G.A. Linear Sobolev Type Equations and Degenerate Semigroups of Operators / G.A. Sviridyuk, V.E. Fedorov. - Utrecht etc.: VSP, 2003.

10. Дезин, А.А. Многомерный анализ и дискретные модели / А.А. Дезин. - Новосибирск: Наука, 1990.

11. Морен, К. Методы гильбертова пространства / К. Морен. - М. : Мир, 1965.

12. Пале, Р. Семинар по теореме Атьи-Зингера об индексе / Р. Пале. - М.: Мир, 1967.

Шафранов Дмитрий Евгенъевич, кандидат физико-математических наук, доцент кафедры уравнений математической физики, Южсн-Уральский государственньй университет (г. Челябинск, Российская Федеращия), shafranovd@mail.ru

Адукова Наталья Викторовна, магистрант кафедры уравнений математической физики, Южно-Уральский государственный университет (г. Челябинск, Российская Федерачия), adnatasha94@mail.ru

Поступила в редакиию 23 июня 2017 г. 